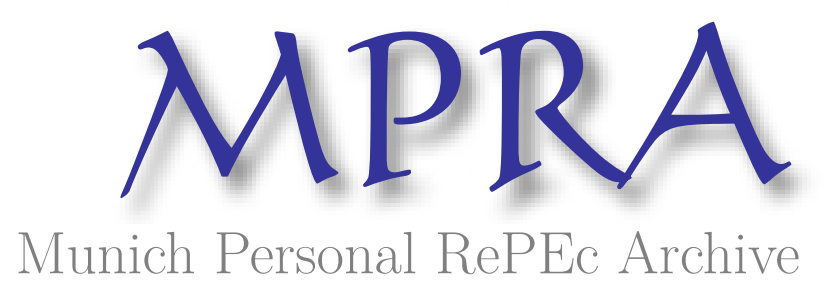

Energy resources, domestic investment and economic growth: empirical evidence from Nigeria

SAIBU, Olufemi Muibi

University of Johannesburg

31 December 2012

Online at https://mpra.ub.uni-muenchen.de/34392/

MPRA Paper No. 34392, posted 06 Mar 2013 21:42 UTC 
Iranica Journal of Energy \& Environment 3 (4): 321-329, 2012

ISSN 2079-2115

IJEE an Official Peer Reviewed Journal of Babol Noshirvani University of Technology

DOI: 10.5829/idosi.ijee.2012.03.04.121204

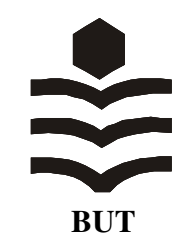

\title{
Energy Resources, Domestic Investment and Economic Growth: Empirical Evidence from Nigeria
}

\author{
Saibu M. Olufemi \\ Department of Economics and Econometrics, \\ University of Johannesburg, Auckland Park 2006, Johannesburg, South Africa
}

(Received: December 4, 2012; Accepted: December 31, 2012)

\begin{abstract}
The paper examined whether investment serves as a channel through energy could promote economic growth in Nigeria. A model that incorporated energy as a separate input and as an indirect input was developed and estimated. The results showed that the potential of investment to enhance economic growth is significantly depressed by the energy resources dependence. Although pubic investment was found to be a channel through which energy resources enhanced economic growth in Nigeria. There is evidence that Dutch disease/resource curse problem is a Nigerian phenomenon as energy abundance is found to significantly impair economic growth in Nigeria.
\end{abstract}

Key words: Energy resources \%Investment \%Economic Growth \%Nigeria

\section{INTRODUCTION}

The focus of this paper is to examine the direct and indirect nexus between energy resources and economic growth. The effects of natural resources in general and energy resources in particular on economic growth have remained an unresolved issue in macroeconomic debate. While many scholars argued that the presence of natural resource in a country is rather a 'curse' than a 'blessing', some had argued that many resource rich countries have succeeded. Several studies have been carried out on the linkage between the resources endowment and the Nigerian growth experiences over the year [1-6]. The bulk of these studies conclude that the resource endowment has not contributed much to the economic well being of Nigeria. Some even considered energy resources as a curse to Nigeria [6]. Though, few other studies found energy resources to have potential of promoting economic growth $[2,4]$ but most often because of the difficulty to justify such positive result in view of poor economic performance in Nigeria, they hardly make any meaningful policy inferences rather they succumbed quickly to the resources curse hypothesis even when they have contrary results. This study is distinct from any previous attempt at examining natural resource impact on economic performance in many other ways. Firstly, the study is country specific, focussing on Nigeria, an oil rich country yet low income country. Most studies on natural wealth and economic growth are cross country studies and Wright et al. [7] has noted statistical problems with some existing studies pointing out "cross-country regressions are notoriously subject to selection bias". Cross-country studies also neglect the individual country traits (e.g. difference in population). Apart from this there other reasons for the choice of Nigeria. Nigerian economy provides a unique and interesting phenomenon. Nigeria is an oil-abundant country with the capacity to produce 2,050,000 barrels per day with the average growth rate of population being $2.5 \%$. About $54 \%$ of the population lives on less than $\$ 1$ per day while $71 \%$ lives on less than $\$ 2$ per day 2011 [8]. Does it mean that abundant natural wealth is contributing sparingly to economic growth?

Corresponding Author: Saibu M. Olufemi, Department of Economics and Econometrics,

University of Johannesburg, Auckland Park 2006, Johannesburg, South Africa.

Tel: +27785788874, E-mails: fsaibu@uj.ac.za \& omosaibu@yahoo.com. 
Iranica J. Energy \& Environ., 3 (4): 321-329, 2012

Table 1: Selected development Indices in Nigeria*

\begin{tabular}{|c|c|c|c|c|c|c|}
\hline Year & Rate of inflation & Unemployment rate & Poverty indices & Percpita income & GDP Growth rate & HDI \\
\hline 2008 & 11.53 & 14.9 & 54 & 2.78 & 5.98 & 0.416 \\
\hline 2009 & 12.59 & 19.7 & 69 & 3.76 & 6.96 & 0.419 \\
\hline 2010 & 13.76 & 21.4 & 58 & 4.78 & 7.98 & 0.423 \\
\hline 2011 & 11.7 & 23.9 & 71 & 4.16 & 7.36 & 0.411 \\
\hline
\end{tabular}

*Sources: National Planning Commission Reports [8]

Secondly, apart from contributing to the debate on the CURSE versus BLESSING prognosis, the study goes further to examine the issue of abundance and dependence as possible explanation of the confusion in the empirical evidence from previous studies. Also the paper also attempt to decompose investment into foreign direct investment, domestic private investment and public investment. The relevance of this decomposition is to determine the relative strength of each channel as another attempt at verifying the private led and public led energy resource exploration hypothesis. The paper is divided into five sections. Apart from this introductory section, section 2 provides a synopsis of issues raised and investigated in the literature while section 3 presents the methodology. Section 4 discusses the empirical results and findings while section 5 summaries with policy implications.

Review of Empirical Literature: A large body of empirical studies has attempted establishing the nature and magnitude of influence of oil and other natural resources endowment on growth. For example Sachs and Warner [9], from a sample of 95 developing countries, found a clear negative relationship between natural resource based exports and growth in the period 1970-1990. They found only two countries in the list of resource-abundant countries that sustained 2 percent per annum growth during 1970-1980. Mehlum et al. [10] investigated whether growth winners and growth losers differs in their institutional arrangements using a sample of eighty seven countries from 1965 to 1990 . They made a distinction between "grabber friendly institutions where rent seeking and production a competing activities and "producer friendly" institutions (where rent seeking and production are complementary activities. They found that more natural resources push aggregate income down when institutions are grabber friendly, while more resources raises income when institutions are producer friendly.

Sachs and Warner [11] extended his previous research that showed that countries with great natural resource wealth tend to grow more slowly than resource-poor countries. They showed that there is little direct evidence that omitted geographical or climate variables explained the negative relationship or that there is a bias resulting from some other unobserved growth deterrent. They maintained that resource abundant countries tend to be high price economies and perhaps as a consequence these countries tended to miss-out on export-led growth. Gylfason and Zoega [12] showed that relying too heavily on natural resources reduced saving, investment and growth as well as lowering the level of output per capita in the long run. They examined 85 countries comprising of both resource-rich and resource poor countries. They concluded that natural resources are an essentially exogenous factor that can hamper economic growth through macroeconomic channels as well as through institutions.

Blute et al. [3] examined relationship between resource abundance and several human welfare indicators. Consistent with the existing literature on the relationship between resource abundance and economic growth the found that, given an initial income level, resource-intensive countries tends to suffer lower levels of human development. While the found only weak support for a direct link between resources and welfare, there is an indirect link that operates through institutional quality.

Papyrakis and Gerlagh [13] examined the direct and indirect effects of natural resource abundance on economic growth. Using a sample of 39 countries, they found that natural resources have negative impact on growth if considered isolation but a positive direct impact on other explanatory variables. However, if transmission channels are included, they found that the overall effect of natural resource abundance on economic growth is strongly negative. They maintained that investment channel is shown to be the most important of the transmission channels examined.

Bhattacharya and Ghura [1] investigated the linkages between oil and growth in Congo during 1960-2004. They examined empirically how natural resource (oil) affects growth in the non-oil sector both directly and indirectly through its impact on the real effective that development of the oil sector had any significant effect on growth of the non-oil sector. However, they maintained that oil sector may have 
indirectly affect the non-oil sector through political instability associated with weakening institution or through real effective exchange rate appreciation. Olomola [4] analyzed the effect of oil rents on economic growth in oil exporting African countries using a sample of 60 countries for the period 1970-2000. He found that oil rent had failed to promote growth in oil exporting African countries. He founds that absence of democracy in oil exporting countries rather than Dutch disease explains why growth is retarded in those countries.

With respect to Nigeria, Olomola and Adejumo [5] maintained that "Dutch Disease" exists in Nigeria. it examined the effect of oil price shock on output inflation, real exchange rate and money supply in Nigeria for a period of 34 years. Budina et al. [2] focused on the role of fiscal policy in managing the volatility of oil wealth and its implication for debt and development. They found that Nigeria's own policy increased rather than smoothed volatility and volatility of expenditure was further increased by debt overhang problems. They emphasized that Nigeria's economy is not improving due to poor fiscal policies in managing expenditure levels and commitments low enough to avoid a crisis is if and when oil prices come down and revenue falls would avoid departments and increase growth of the nation.

Gbadebo et al. [14] analyzed the relationship between crude oil sector and the Nigerian economic performance using OLS from period 1970-2005. He maintained that crude oil consumption and export has contributed to the improvement of the Nigerian economy. The author examined a direct effect of crude oil production on economic growth in Nigeria; he did not consider the indirect effect neither did he explore the transmission mechanism of oil wealth to economic growth. Sala-i-Martin and Subramanian [15] showed that oil exert a negative and nonlinear impact on economic growth in Nigeria. They also said waste and corruption from oil rather than Dutch disease has been responsible for Nigeria's poor long run economic performance. The authors focused on institution and Dutch disease as the only transmission channel of oil wealth to economic growth in Nigeria. They neglected investment channel and did not consider indirect effect.

The general observation therefore is that the issue of energy resources and economic growth still an empirical issue with respect to country like Nigeria, the failure of previous studies to examine many other channels might also contributed to the controversy whether the oil sector is the culprit or victim of economic stagnation in the country.

\section{Empirical Methodology}

Theoretical Framework: The theoretical modelling for the relationship between energy resources and economy growth follows directly from the standard Solow theoretical model. However, To include non-renewable resource in the standard Solow model We assume that a fixed amount of energy resources (E) is available to the economy in each production period but which is exhaustible when they are used in production and that output is produced according to

$Y=A k^{\prime \prime} E^{\$} L^{1-"-\$}$

where $\$$ is between zero and one and " $+\$<1, \mathrm{~L}$ and $\mathrm{K}$ represent human and physical capital inputs and $\mathrm{A}$ represent the index of exogenous technology and multiplies the whole production function rather than the augmenting labour inputs and the Solow model suggests. The production function exhibits constant returns to scale in $\mathrm{L}, \mathrm{K}$ and $\mathrm{E}$ so output doubles only when all the inputs are doubled. In similar manner with the standard Solow model, the economy is assumed further to exhibits exogenous technological progress and exogenous population growth and capital accumulates in the standard fashion

$\frac{\Delta A}{A}=g_{A}$

$\frac{\Delta L}{L A}=n$

) $K=s Y-\mathrm{MK}$

where $s$ is the constant rate of investment an $M$ is the constant rate of depreciation. If $\mathrm{R}_{0}$ stands for the initial stock of the energy resources, when the economy uses amount $\mathrm{E}$ of energy in production, the resources stock is depleted and the resources stock obeys a differential equation similar to the capital accumulation equation, only it dissipates rather than accumulates:

$\dot{R}=-E$

In the long run, just like the saving rate assumption of the Solow model, a constant fraction $\left(e_{E}=E / R\right)$ of the remaining stock of energy resources is used in the production in each period [16]. By dividing equation 5 by $R$, the remaining stock of energy in the economy is observed to decline over time at the rate $\left(s_{E}\right)$ : 
$\frac{\dot{R}}{R}=-S_{E}$

And therefore the behaviour of stock of energy resources over time can be describes by

$$
E(t)=R_{0} e^{-s_{E}^{t}}
$$

The stock of energy resources decline exponentially and since $\mathrm{E}=S_{E} R$ then the amount of energy used in the production each period is given as

$$
E=s_{E} R_{0} e^{-s_{E}^{t}}
$$

Substitution equation 8 into equation 1 and expressing the production function in terms of capital output ratio, we have

$$
Y=A^{\frac{1}{1-\alpha}}\left(\frac{K}{Y}\right)^{\frac{1}{1-a}}\left(s_{E} R_{0} e^{-s_{E}^{t}}\right)^{\frac{\beta}{1-\alpha}} L^{1 \frac{\beta}{1-\alpha}}
$$

Taking the $\log$ and derivatives of Equation 9, the growth rate of total output along a balanced growth path is

$g_{y}=g-\varphi s_{E}+(1-\varphi) n$

where $g=g_{n} / 1-"$ and $n=\$ / 1-"$ an given the assumption of constant population growth, then the final growth rate of output can be given as

$g_{y}=g-n\left(s_{E}+n\right)$

This expression in equation (11) gives rise to three significance policy implications. First, if $\$=0$, energy resources plays no role in the model and $g_{y}=g$ just like the basic Solow model with technology progress. Second, the long run, growth rate of the economy with energy resources depends on more than just the rate of technology change, energy resources' abundance $(\$)$ and dependence in production $\left(s_{E}\right)$ as well as the population growth rate $n$ now plays significant roles. Third the growth rate of the economy depends among other fundamentals on the tug of war between technological progress $(g)$ and the combined effects of energy dependence $n\left(s_{E}\right)$ and the diminishing returns on introduced by energy resources as non renewable factor $n n$.
Lastly, the more dependence on energy resources (that is $\left(\$\right.$ and $\left.s_{E}\right)$, the production is the lower the long run growth will be. This will be so because the more important the energy resources is, the sharper the diminishing returns to capital and labour in the economy $\left(-n\left(s_{E}+n\right)\right)$.

More importantly, equation 11 implies that investment either in human development or capital accumulation is an important channel energy resource could affect the economic growth in the long run. According to the investment channel, energy resource abundance may reduce private and public incentive to accumulate human capital due to a high level of non-wage income e.g. dividends social spending and low taxes. Energy resource rich nations may underestimate the longrun value of education, thereby crowding out human capital, which lead to low productivity and in turn low economic growth. Also, abundant energy resources may blunt private and public incentives to save and invest thereby retarding economic growth.

Model Specification: The model represented by equation 9 can be rewritten in log linear form as

$R G D P=T_{0}+T_{1} \mathrm{GENR}+T_{2} \mathrm{GZ}_{i}$

Equation 9 implies that growth rate (RGDP) depends directly on both human and physical capital investment, Energy Resource (ENR) which could be decomposed into two components (abundance $\left(E_{a}\right)$ and dependency $\left(E_{d}\right)$ and on a vector of other explanatory variables $\mathrm{Z}$ comprising investment in physical capital (IF), foreign direct investment (FDI) investment in human capital (IH), political regime (PR, 1 for democracy and zero for otherwise); Real exchange rate (ER) and economic openness (OP). The incorporation of all these variables is to accommodate other possible channel of energy influence on economic growth.

Following Acemoglu et al. [17] and Olomola and Adejumo [5], Dutch disease and institution channels are assumed to be operational in Nigeria. Energy resource discovery is perceived to give rise to inefficiency in another sector especially the industrial sector. This leads to government failure to conduct effective policies, which then leads to slow economic growth. The institutional channel of its part, assumes that the prevailing economic institution is determined by political power, which is in turn determined by prevailing political institutions and distribution of existing resources. Political institutions could be dictatorship or liberal. Institutions may be

\footnotetext{
1 where $g_{y}$ in equation 9 is now represented as $r g d p$ and $g$ being a constant is represented by $T_{0}$. $\mathrm{Z}$ represents other macroeconomic variables that might also impact on the growth of real output.
} 
grabber friendly or producer friendly. In grabber friendly institutions, abundant natural resources will push down aggregate income while in producer friendly; natural resource abundance will increase aggregate income.

To determine the indirect effect and relative importance of the transmission channels, energy resource will regressed on the various measures of the channels in variable $\mathrm{Z}$ in equation 9 that is:

$Z=a_{0}+a_{1} \mathrm{G} E N R_{i}+\mu$

where $\mathrm{Z}, a_{0}, a_{1}$ and $\mu$ are vectors of which each elements is associated with the indices of IF, RER, FDI,IH, RER, OP and DR. Since energy resources explain part of the variation in investment, real exchange rate and other variables, the direct and indirect effects of energy resources on economic growth are derived by substituting equation (13) into (9).

$$
\begin{aligned}
& R G D P=\left(T_{0}+a^{0 i}\right)+T_{1} \mathrm{G} I N V_{i}+ \\
& T_{2} \mathrm{G} E N R_{i}+\left(T_{3}+T_{3} a_{1}\right) \mathrm{G} Z_{i}+e
\end{aligned}
$$

where $T_{2}$ is the direct effect of energy resources on growth, $T_{3} a_{1}$ is the indirect effect of energy resources on growth and $e$ are the residuals of equation (14).

Data Description and Analytical Technique: The paper uses annual data to examine the direct and indirect relationship between energy resources and energy resources for Nigeria for the period 1970 to 2010. Energy resources will be measured in three different ways. First energy resource is measured by total oil production multiplied by the international oil prices prevailing at each year. Second, oil abundance measured by total oil revenue in each year while the third is energy resource dependence proxied by the share of oil revenue in total government revenue. The real GDP was measured in constant price (2000 as base year) denominated in US Dollars and real exchange rate (Nominal Exchange Rate of naira adjusted for inflation rate differential with the U.S. dollar) were taken from International Financial Statistics (IFS). Investment variables and Average World Oil Prices dominated in US Dollars in constant price (2000 as the base year) were taken from World Economic Indicators. All the variables were expressed in log forms before the analysis. The political regime is represented by a dummy 1 for periods of elected head of state and zero for others. A dummy variable for institution is also included. 1 for period when there was substantive Minister of petroleum and zero for others.
The cointegration analysis of Johansen [18, 19] and Vector Error Correction Model (VECM) are employed. Using the above VECM technique four steps were involved. The first step involving testing the stationarity of the series or their order of integration as the series need to be integrated of same order as implied by Equation 1 to Equation 2. The second step is to examine the presence of a long run relationship among the variables in equations. However, the long run coefficients are estimated using the associated cointegration model proposed by Johansen and Julius [19]. Once the cointegration is confirmed in the model, the residuals from the equilibrium regression can be used to estimate the error correction model in the third step. Finally, the forth step involves conducting Granger causality/Wald Lag Restriction test to determine the direction and the significance of the causal relationship among the variables. The validity and efficiency of VECM model depend crucially on the lag structure. The model lag length selection was determined by both Schwarz (SIC) and Akaike (AIC) Information Criterion. Lastly, several of diagnostic tests-which are tests of normality, autocorrelation, heteroscedasticity in the error term and the stability of model will be conducted to examine the validity and reliability of these models. The results of diagnostic tests will be analysis and if there is any nonconformity with aprior expectation appropriate adjustment will be made to the model to correct such deficiency.

\section{RESULTS AND DISCUSSION}

\section{Unit Root and Cointegration Properties of the Variables:}

Since OLS estimates of relationships among macroeconomic variables have been found to be inefficient and biased, the first step in analyzing the relationship among macroeconomic variables therefore is to whether the variables in the model are stationary [20]. Using the augmented Dickey-Fuller (ADF) test, the results of the test are presented in Table 1 . The Table 1 shows that all variables were not stationary at their levels for $\mathrm{ADF}$ while the first order differences of the variables are stationary.

With the confirmation of the stationarity properties of the variable, the next logical step is to determine the cointegration properties. This is important since if they are co integrated, a long run relationship between the variables would exist even if they are individually non stationary and we could then estimate the vector error correction for the model. The estimated results for the cointegration tests are reported in Tables 2, based on the Johansen cointegration technique. The superiority of 
Iranica J. Energy \& Environ., 3 (4): 321-329, 2012

Table 1: ADF Unit root Tests for Stationarity

\begin{tabular}{|c|c|c|c|}
\hline Variable Definition & Symbols & Level & First Difference \\
\hline Energy Abundance & LENRA & -3.649 & -6.145 \\
\hline Energy Dependence & LENRD & -2.747 & -6.084 \\
\hline Real Gross Domestic Product & LRGDP & -2.302 & -5.756 \\
\hline Foreign Direct Investment & LFDI & -0.086 & -9.615 \\
\hline Human Capital Investment & LHCINV & -2.862 & -5.649 \\
\hline Public Investment & LPUINV & -2.241 & -11.946 \\
\hline Price Indices & LCPI & -0.368 & -3.427 \\
\hline Trade Openness & LOPEN & -2.569 & -7.067 \\
\hline Private Investment & LPRINV & -2.481 & -8.062 \\
\hline Exchange Rate & LEXRT & 0.0325 & -.5 .243 \\
\hline Critical Values & @ $1 \%$ & -3.616 & -3.621 \\
\hline
\end{tabular}

Table 2: Cointegration tests Results

\begin{tabular}{|c|c|c|c|c|c|c|}
\hline \multicolumn{7}{|c|}{ Series: LRGDP LENRA LENRD LEXRT LFDI LHINV LOPEN LPRINV LPUINV LCPI Lags interval (in first differences): 1 to 1} \\
\hline Hypothesized & Trace & 0.05 & & Max-Eigen & 0.05 & \\
\hline No. of CE(s) & Statistic & Critical Value & Prob.** & Statistic & Critical Value & Prob.** \\
\hline None * & 408.2820 & 239.2354 & 0.0000 & 100.1610 & 64.50472 & 0.0000 \\
\hline At most $1 *$ & 308.1210 & 197.3709 & 0.0000 & 90.03214 & 58.43354 & 0.0077 \\
\hline At most $2 *$ & 218.0888 & 159.5297 & 0.0001 & 59.60426 & 52.36261 & 0.0589 \\
\hline At most $3 *$ & 158.4846 & 125.6154 & 0.0020 & 45.56177 & 46.23142 & 0.0802 \\
\hline At most $4 *$ & 112.9228 & 95.75366 & 0.0192 & 38.19862 & 40.07757 & 0.2269 \\
\hline At most $5 *$ & 74.72418 & 69.81889 & 0.0599 & 27.71632 & 33.87687 & 0.1756 \\
\hline At most 6 & 47.00786 & 47.85613 & 0.1980 & 22.95023 & 27.58434 & 0.4048 \\
\hline At most 7 & 24.05762 & 29.79707 & 0.2423 & 13.52938 & 21.13162 & 0.2685 \\
\hline At most 8 & 10.52824 & 15.49471 & 0.2524 & 9.218113 & 14.26460 & 0.2524 \\
\hline At most 9 & 1.310129 & 3.841466 & & 1.310129 & 3.841466 & \\
\hline
\end{tabular}

Trace test indicates 6 cointegrating eqn(s) at the 0.05 level

$*$ denotes rejection of the hypothesis at the 0.05 level

Max-eigenvalue test indicates 3 cointegrating eqn(s) at the 0.05 level

$*$ denotes rejection of the hypothesis at the 0.05 level

**MacKinnon-Haug-Michelis (1999) p-values

Johansen's approach compared to Engle Granger's residual based approach lies in the fact that Johansen's technique is capable of detecting multiple cointegrating relationships among the variables [21, 22]. The estimation procedure of Johansen test is very sensitive to the choice of lag length hence the Schwarz Bayesian Information criterion (SBC) is used to fix the optimal lag length at one. The estimated results indicate that multiple cointegrating long run relationship despite their non stationarity and thus confirming that there is long run equilibrium relationship between energy resources investment and economic growth in Nigeria. The presence of co-integration among these variables is consistent with results found by other studies such as Saibu [23] and Bekhet and Yutop [24] which had established the presence of co-integration relationship between energy and macroeconomic variables like economic growth and investment
Relative Effects of Energy and Investment on Economic Growth: In order to analysis the effect of energy resources on economic growth, two different classification of energy was used that is energy dependence (ENRD) and energy abundance ENRA). Four investment variables were used Public Investment (PUINV), Private investment (PRINV), Foreign Direct Investment (FDI) and Human capital development (HINV). Exchange rate (EXRT), trade openness (LOPEN) and inflation (LCPI) were added as conventional growth determinant. Political regime (POLDUM) was also included to account for the possible effect of democratic governance could have on the relationship between energy use policy and economic growth. Based on this classification, Table 3 presents the estimates of equation 9 and 11. Equation 9 estimates is reported as the Model I while Model II and III report the estimates of the equation 11 when the energy variables were interacted with each of the investment variables. 
Iranica J. Energy \& Environ., 3 (4): 321-329, 2012

Table 3: Regression Estimates of Energy and Investment effects on Economic Growth

\begin{tabular}{|c|c|c|c|}
\hline Series & Model I & MODEL II(ENRD) & MODEL III(ENRA) \\
\hline \multirow[t]{2}{*}{ LENRD(-1) } & 0.591196 & & \\
\hline & [ 1.20141$]$ & & \\
\hline \multirow[t]{2}{*}{$\operatorname{LENRA}(-1)$} & -0.811068 & & \\
\hline & {$[-35.4459]$} & & \\
\hline \multirow[t]{2}{*}{ LHINV(-1) } & 0.219165 & & \\
\hline & [ 7.49220] & & \\
\hline \multirow[t]{2}{*}{ LPRINV(-1) } & 0.627654 & & \\
\hline & [ 20.7795] & & \\
\hline \multirow[t]{2}{*}{ LFDI(-1) } & -0.374466 & & \\
\hline & {$[-16.4508]$} & & \\
\hline \multirow[t]{2}{*}{ LPUINV(-1) } & -0.685696 & & \\
\hline & {$[-18.1222]$} & & \\
\hline \multirow[t]{2}{*}{ LENR*HINV(-1) } & & -0.883713 & -2.117487 \\
\hline & & {$[-5.73270]$} & {$[-6.32425]$} \\
\hline \multirow[t]{2}{*}{ LENR*PRINV(-1) } & & -0.919637 & -1.817836 \\
\hline & & {$[-5.68370]$} & {$[-4.28210]$} \\
\hline \multirow[t]{2}{*}{ LENR*FDI(-1) } & & -0.369720 & -0.445189 \\
\hline & & {$[-2.78067]$} & {$[-1.26676]$} \\
\hline \multirow[t]{2}{*}{ LENR*PUINV(-1) } & & 1.550221 & 3.929554 \\
\hline & & [ 6.70482] & [ 6.88004] \\
\hline \multirow[t]{2}{*}{ LEXRT(-1) } & 0.183965 & 0.997203 & 1.668400 \\
\hline & [ 4.36103] & [ 4.19143] & {$[2.75660]$} \\
\hline \multirow[t]{2}{*}{ LOPEN(-1) } & -0.412013 & 3.027013 & 5.533135 \\
\hline & {$[-4.22141]$} & [ 5.93232] & [ 4.01248] \\
\hline \multirow[t]{2}{*}{ LCPI(-1) } & 0.454916 & -2.127183 & -4.942869 \\
\hline & [ 11.6071] & {$[-8.93227]$} & {$[-7.81922]$} \\
\hline \multirow[t]{2}{*}{ POLDUM(-1) } & 0.319480 & -2.130780 & -5.083080 \\
\hline & [ 10.2585] & [-11.2979] & {$[-10.2647]$} \\
\hline Adjusted $\mathrm{R}^{2}$ & 0.7492 & 0.5591 & 0.4273 \\
\hline F-statistics & 31.2861 & 30.5256 & 22.8560 \\
\hline
\end{tabular}

Model I shows that all the variable were significant except energy dependence. Human capital development and private investment were positive and significant. Public investment and foreign direct investment as well as trade openness were on the other hand negative but significant which implies that public investment and FDI are possibly not yielding the desired results as expected and trade liberalisation policy might not in the long run be good for the Nigeria as it might have resulted in negative incentives for promoting local infant industries. The FDI inflows had concentrated in the energy industries and such industry had been found to have little backward linkage with the economy. Public investment in Nigeria had been more of eye service, several millions of naira is budgeted but yet hardly will such allocation translate to real infrastructural development.

Exchange rate and price changes were significant and also positive. Exchange rate depreciation as noted in the literature promotes export while price increase could also serve as incentive to investors to produce more. Economic intuition suggests that a dose of both higher exchange rate and inflation is good for propelling economy that is depressed and also to raise the level of productivity in the economy. The increase in exchange rate and price level therefore might have served as stimulant for the recent increase in economic growth experienced in Nigeria. The result further showed that political democratisation had also impacted positive and significantly on the economy. Though, the economy reality is still far below expectation, what the result just implies is that the situation now is better than the period of military rule in Nigeria.

Only energy abundance was significant but negative while energy dependence was insignificant but positive, the positive effect of energy dependence implies that Nigeria economy like modern economy in the world depends on energy. However, the negative effect of energy abundance suggests that the resource curse hypothesis is real a Nigerian phenomenon. The more oil resources explored the lower the economic well being of the people. The bulk of energy used in Nigeria is imported hence the abundance of energy resources had not significantly influenced economic well being of the people. Indeed, the official report from government had 
also confirmed that the higher growth rate experienced in Nigeria in recent years were from non oil sector and that even in some few years oil sector experienced negative growth.

Model II and II incorporate the interaction between the two energy resources variables and investment variable as a way of testing for investment channels. Model II used energy dependence while model II use energy abundance. The interaction significantly altered the estimates of the model. First, energy dependence that was positive became negative. The most significant change is that fact that energy dependence that was positive and insignificant became negative and significant. This suggests that investment play a significant role in the pass through effect of energy use in Nigeria. However given the positive effect of private investment on economic growth, it implies that energy uses rather than enhancing the growth potential of investment, it depresses it. However, the only exception is the public investment, public investment that was negative before the interaction became positive and remains significant. This shows that energy resources had boosted the contribution of public investment in the economy. Thus is not surprising as the bulk of government revenue comes from energy resources. Increase in energy resources use, exploration and consumption lead to increase in government revenues and hence greater public investment spending.

\section{CONCLUSION}

The direct and indirect effect of energy resources has been examined in this paper and the results show that energy and investment among other variables are key determinants of economic growth in Nigeria. However, the effects of either energy resources or investment variable depend on the type or classification of such variable. While energy dependence seems growth enhancing, energy abundance seem to depress economic growth in Nigeria. Similarly while private investment and human capital development enhance economic growth both public investment and foreign direct investment depress economic growth in Nigeria. The result also showed that changes in price and exchange rate positively influence the growth rate of Nigeria economy; trade liberalisation in form of trade openness reduces economic growth potential in Nigeria.

The central issue in this paper is whether investment channel could also be added to existing channels of energy effect on economic growth, the answer is yes.
The result showed that the potential of human capital development, private investment to promote economic growth were reduced when the energy use and abundance were allowed to interact with them. Only public investment potentials became enhances suggesting that the only channel through energy had contributed positively to the growth of Nigeria economy is the public investment channel.

The policy implication of this result is that energy policy has to be redesign to be investment friendly. The lack of adequate supply of the bulk of energy use in the country from domestic sources had added significant cost of production doing business in Nigeria, this serves as disincentive to existing and potential investors. The consequence of such disincentive is low productivity and low economic activity and growth. The current high growth rate might be transient that cannot be sustainable if adequate attention is not paid to the link between energy policy and overall investment overhead cost arising from the energy product market inefficiency.

\section{REFERENCES}

1. Bhattacharya, R. and D. Ghura, 2006. Oil and Growth in the Republic of Congo (EPub): International Monetary Fund.

2. Budina, N. and S. van Wijnbergen, 2008. Managing oil revenue volatility in Nigeria: The role of fiscal policy. Africa at a Turning Point? Growth, Aid and External Shocks, pp: 427-59.

3. Bulte, E.H., R. Damania and R.T. Deacon, 2005. Resource intensity, institutions and development. World Development, 33(7): 1029-1044.

4. Olomola, P.A., 2007. Oil wealth and economic growth in oil exporting African countries. African Economic Research Consortium, pp: 170.

5. Olomola, P.A. and A.V. Adejumo, 2006. Oil price shock and macroeconomic activities in Nigeria. International Research Journal of Finance and Economics, 3: 28-34.

6. Olusi, J. and M. Olagunju, 2005. The Primary Sectors of the economy and the Dutch Disease in Nigeria. The Pakistan Development Review, pp: $159-175$.

7. Wright, G. and J. Czelusta, 2002. Resource-based economic growth, past and present. Palo Alto, CA: Stanford University, 11: 1-46. http:// weber.ucsd.edu/ $\sim$ carsonvs/ papers/580.PDF.

8. National Planning Commission, 2007. Nigeria Millennium Development Goals, 2006 Report. 
9. Sachs, J.D. and A.M. Warner, 1997. Sources of slow growth in African economies. Journal of African economies, 6(3): 335-376.

10. Mehlum, H., K. Moene and R. Torvik, 2006. Institutions and the Resource Curse. The Economic Journal, 116(508): 1-20.

11. Sachs, J.D. and A.M. Warner, 2001. The curse of natural resources. European economic review, 45(4): 827-838.

12. Gylfason, T., 2001. Natural resources, education and economic development. European economic review, 45(4): 847-859.

13. Papyrakis, E. and R. Gerlagh, 2004. The resource curse hypothesis and its transmission channels. Journal of Comparative Economics, 32(1): 181-193.

14. Gbadebo, O.O. and C. Okonkwo, 2009. Does energy consumption contribute to economic performance? Empirical evidence from Nigeria. Journal of Economics and International Finance, 1(2): 044-058.

15. Sala-i-Martin, X. and A. Subramanian, 2003. Addressing the natural resource curse: An illustration from Nigeria, National Bureau of Economic Research.

16. Jones, C.I., 2002. Sources of US economic growth in a world of ideas. The American Economic Review, 92(1): 220-239.

17. Acemoglu, D., S. Johnson and J.A. Robinson, 2005. Institutions as a fundamental cause of long-run growth. Handbook of economic growth, 1: 385-472.
18. Johansen, S., 1988. Statistical analysis of cointegration vectors. Journal of economic dynamics and control, 12(2): 231-254.

19. Johansen, S. and K. Juselius, 1990. Maximum likelihood estimation and inference on cointegration-with applications to the demand for money. Oxford Bulletin of Economics and statistics, 52(2): 169-210.

20. Lise, W. and K. Van Montfort, 2007. Energy consumption and GDP in Turkey: Is there a co-integration relationship? Energy Economics, 29(6): 1166-1178.

21. Asafu-Adjaye, J., 2000. The relationship between energy consumption, energy prices and economic growth: time series evidence from Asian developing countries. Energy economics, 22(6): 615-625.

22. Pradhan, R.P.P., 2010. Energy consumption-growth nexus in SAARC countries: using cointegration and error correction model. Modern Applied Science, 4(4): 75-90.

23. Saibu, M., P. Wosa and M. Agbeluyi, 2011. Financial Development, Foreign Direct Investment and Economic Growth in Nigeria. Journal of Emerging Trends in Economics and Management Sciences, 2(2): 146-154.

24. Bekhet, H.A. and N.Y.M. Yusop, 2009. Assessing the Relationship between Oil Prices, Energy Consumption and Macroeconomic Performance in Malaysia: Co-integration and Vector Error Correction Model (VECM) Approach. International Business Research, 2(3): 152-175. 